\title{
Media use during adolescence: the recommendations of the Italian Pediatric Society
}

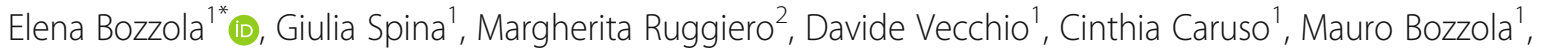 \\ Anna Maria Staiano ${ }^{1}$, Rino Agostiniani ${ }^{1}$, Antonello Del Vecchio ${ }^{1}$, Giuseppe Banderali', Diego Peroni ${ }^{1}$, \\ Alberto Chiara', Luigi Memo ${ }^{1}$, Renato Turra', Giovanni Corsello ${ }^{1}$ and Alberto Villani ${ }^{1}$
}

\begin{abstract}
Background: The use of media device, such as smartphone and tablet, is currently increasing, especially among the youngest. Adolescents spend more and more time with their smartphones consulting social media, mainly Facebook, Instagram and Twitter because. Adolescents often feel the necessity to use a media device as a means to construct a social identity and express themselves. For some children, smartphone ownership starts even sooner as young as 7 yrs, according to internet safety experts.

Material and methods: We analyzed the evidence on media use and its consequences in adolescence.

Results: In literature, smartphones and tablets use may negatively influences the psychophysical development of the adolescent, such as learning, sleep and sigh. Moreover, obesity, distraction, addiction, cyberbullism and Hikikomori phenomena are described in adolescents who use media device too frequently. The Italian Pediatric Society provide action-oriented recommendations for families and clinicians to avoid negative outcomes.
\end{abstract}

Conclusions: Both parents and clinicians should be aware of the widespread phenomenon of media device use among adolescents and try to avoid psychophysical consequences on the youngest.

Keywords: Media device, Adolescence, Smartphone, Addiction, Internet

\section{Background}

Media device use, especially interactive apps, including social network and video games, is severely increasing in childhood [1].

Considering social network, Facebook is the most used platform with 2.4 billion users worldwide followed by Instagram and Twitter [2].

In particular, among adolescents, the age of initial use of social network is dropping to $12-13$ years nowadays because of the necessity to use it as a means to construct a social identity and express themselves [2] [3].

According to ISTAT, $85.8 \%$ of italian adolescents aged 11-17 years have regular access to smartphones, and over $72 \%$ access Internet via smartphones. More girls (85.7\%) use smartphone compared to boys [4]. Moreover, recent

* Correspondence: elena.bozzola@opbg.net

${ }^{1}$ Italian Pediatric Society, Rome, Italy

Full list of author information is available at the end of the article studies reported that $76 \%$ of adolescents use social network, with $71 \%$ of them using more than one social network apps [5]. Almost half of the adolescents are constantly online [6].

Online communication, education and entertainment are increasingly taking place online. In Europe, Eurostat analysis evidenced a great growth of Internet access from $55 \%$ in 2007 to $86 \%$ in 2018, and Internet access through a mobile device from 36\% in 2012 to 59\% in 2016 [7, 8].

Considering worldwide data, the number of smartphone users is forecast to reach 2.87 billion users in 2020 [9].

Moreover, problematic internet use is actually considered an important public health concern in specific groups such as the adolescents. For example, Chinese and Japan studies report that 7.9 to $12.2 \%$ of adolescents were problematic Internet users $[10,11]$. In India, the prevalence is even higher, reaching $21 \%$ in vulnerable groups [12]. 
In Italy few data exist about media use in adolescence $[4,13,14]$.

A survey pointed out that $75 \%$ of adolescents use a smartphone during school activities and 98\% use it over midnight. Many adolescents sleep with their smartphone under pillows (45\%) and check smartphone during the night $(60 \%)$. Moreover, $57 \%$ of them use smartphone within ten minutes from awaking and $80 \%$ fall asleep holding their smartphone [14].

\section{Aim}

Aim of the study is to describe the evidence on media use and its consequences among adolescents.

\section{Materials and methods}

For the purpose of the study we investigated both positive and negative outcomes of media use on adolescents, considering health related problems, in order to give recommendations to optimize the use and to reduce negative consequences. A search strategy consisting of a systematic review of the thematic scientific literature published from January 2000 to April 2019 using the Preferred Reporting Items for Systematic Reviews and Meta-Analyses (PRISMA) guidelines. A comprehensive literature search of the MEDLINE/PubMed, Cochrane Library, the Cumulative Index to Nursing and Allied Health Literature (CINHAL) databases was conducted. The search algorithm was based on a combination of the following terms: media use, social network, video games, childhood, adolescence, family, parents, smartphone, internet, learning, sleep, sight, addiction, muscle, distraction, hikikomori, social withdrawal, cyberbullying, positive aspects, negative aspects. No language restriction was applied.

\section{Results}

\section{Learning}

Social network and smartphone may be related to learning consequences, such as low academic outcomes, reduced concentration and procrastination [15-17].

Problematic smartphone use (PSU) correlates to a surface approach to learning more than to a deep approach one [18]. Among the negative consequences of a surface approach, the most frequent are: reduced creativity, organization skills, own thinking and comprehension of information $[19,20]$. Moreover, students with a surface approach to learning just aim to do only what is strictly necessary to study, reaching less satisfactory results than deeper learners $[15,21-24]$.

\section{Sleep}

According to a recent literature review, the use of media devices during bed-time is frequent: $72 \%$ of children and $89 \%$ of adolescents have at least one media device in the bedroom [25]. The pre-sleep smartphone use has been reported to interfere with both sleep duration and quality [26, 27].

Moreover, a lot of health problems have been described in relation to poor sleep quality: alcohol use disorders, depression, eye syndromes, body fatigue, obsessivecompulsive disorder and increased susceptibility to colds and fever [28-33].

The circadian rhythm can be negative influenced by pre-sleep smartphone use, leading to inadequate sleeping: increased sleep latency, arousal and reduced sleep duration by approximately $6.5 \mathrm{~h}$ on weekdays [34-36].

Electromagnetic radiations and bright smartphones lights can cause physical discomfort such as muscular pain or headaches [37-39].

In addition, recent researches suggested that either inadequate sleep quality or sleep duration are related to metabolic conditions such as diabetes and cardiovascular disease or psychological problems such as depression or substance abuse [40, 41].

The number of adolescents with a sleep duration shorter than the one recommended by National sleep Foundation duration has increased, mainly among the girls ( $45.5 \%$ vs $39.6 \%$ in boys) [ 42 ].

Finally, a 5 or more hours daily of media devices use has been related to a higher risk of sleep problems when compared to a $1 \mathrm{~h}$ use daily [43].

\section{Sight}

The increased use of smartphones may result in ocular problems such as dry eye disease (DED), eye irritation and fatigue, burning sensation, conjunctival injection, decreased visual acuity, strain, fatigue acute acquired comitant esotropia (AACE) and macular degeneration $[44,45]$.

During smartphone use there is a reduction of the blink rate to $5-6 / \mathrm{min}$ that promotes tear evaporation and accommodation, leading to DED [46-48]. Luckily, a 4 week stop of smartphone use may led to clinical improvement in DED patients [49].

As for AACE, the close reading distance can increase the medial rectus muscles tone, causing an alteration of both vergence and accommodation. As well as in DED, clinical symptoms may improve refraining from smartphones [50, 51].

\section{Addiction}

One of the most problematic aspects of smartphones and Internet use in adolescents is addiction. Addiction is referred to someone obsessed by a specific activity which interferes with dailies activities [52].

In case of smartphone addiction, persons continuously check e-mails and social apps. The easy access to smartphone skills during the day facilitates the spreading of this kind of addiction [53]. The smartphone use even 
during a face-to-face communication is an increased phenomena as well. It is called "phubbing" [54].

As suggested by previous studies, smartphone addiction may be compared to substance-use addiction [55].

Diagnostic criteria for smartphone addiction have been proposed in order to facilitate an early recognition of it [56].

According to the Teen Smartphone Addiction National Survey questionnaire conducted from 2016 to 2018, $60 \%$ of teens' friends, in their estimation, are addicted to their phones [57]. Actually, few countries classify addiction as a disease. This is probably the reason why we have few data on media device addiction in adolescence.

A recent Survey by the National Information Society Agency in 2012 evidenced that smartphone addiction in Chorea was $8.4 \%$ [58].

Some Studies emphasized risk factors related to smartphones addiction such as personality and sociodemographic features but also parental attitude. In details, concern, loss of controlling tolerance, withdrawal, instability and impulsiveness, mood modification, lies, loss of interest have been identified as risk factors of smartphone addiction [59].

Considering gender factors, previous researches described that females spent more time on smartphones and had almost 3 times more risk for smartphone addiction than males $[60,61]$. It has also been reported that female addiction may be related to a stronger desire for social relationships [62].

Regarding parental attitude toward smartphone use, parental education is important to treat adolescents with addictions $[63,64]$. In this context, parents may prevent smartphone addiction among adolescents by providing support. In fact, a good parent-adolescent relationship may reduce social anxiety and increase security and selfesteem [65]. On the other hand, parental attachment and insecurity may increase the risk of smartphones addiction in adolescents [66].

Main psychological problems correlated to addiction are: low self-esteem, stress, anxiety, depression, insecurity and solitude $[18,67]$.

School outcomes may be affected as well because smartphone addiction may led adolescents to ignore responsibilities and to spend time unproductively [68, 69].

Internet is often used to escape from negative feelings and solitude, avoid face-to-face interactions, increase self-esteem, enhancing the risk of depression, social anxiety and addiction [70, 71].

Smartphone addiction has been related to two phenomena: fear of missing out (FOMO) and boredom.

FOMO may be described as the apprehension of loose experiences and the consequent wish to remain constantly socially connected with the others. FOMO generates the necessity to check continuously social app in order to keep up to date on friends' activities [72].

Boredom is defined as an unpleasant emotional state, related to lack of psychological involvement and interest associated with dissatisfaction. People may try to cope with boredom by seeking additional stimulation and compulsively using smartphones [73-75].

Adolescents, who are more vulnerable, have a higher risk of boredom and of pathological use of on-line communication applications [76]. On the contrary, smartphone addiction could be negatively influenced by face to face adolescent contacts [77].

\section{Muscle and skeleton}

Problematic smartphone use (PSU) has been related to skeletal problems, muscles pain, sedentary lifestyle, lack of physical energy and weakened immunity $[78,79]$.

Some Chinese reports, describe that $70 \%$ of adolescents experienced neck pain, $65 \%$ shoulder pain, $46 \%$ wrist and finger pain. Musculoskeletal disorders related to smartphones may be influenced by many factors, including smartphone display size, number of text messages sent and hours daily spent on smartphones [80, 81].

Moreover, during smartphone use, a non physiological posture may lead to cervical problems. For example, a neck flexion $\left(33-45^{\circ}\right)$ may cause musculoskeletal consequences especially in the neck region [82, 83].

In particular, texting is one of the most contributing factor of stress on the cervical spine and of neck pain in those who spent $5.4 \mathrm{~h}$ a day on their smartphone [82, 84].

\section{Distraction}

Smartphones activities are associated with higher cognitive distraction and with lower awareness occasionally endangering the lives of users [85].

The risk of distraction is higher in case of large smartphone screens and in case of gaming [86].

Dramatic data showed that vehicle crashes are one of the major causes of injuries in children. The USA experienced an increase of $5 \%$ of motor vehicle fatalities in adolescents $[87,88]$. This may be related to a PSU. In fact, pedestrians using internet and smartphones have a high risk to engage traffic accident because they less frequently look both way and cross the road with a minor attention [89]. In particular, music listeners have a decreased situational awareness [90].

In this context, the role of parental modeling is crucial in adolescent behaviors development: adolescents with parents engaging in cell phone-related distracted driving are more likely to use a cell phone while driving themselves. A study conducted on 760 parents while children (4-10 years) were in the vehicle observed that $47 \%$ of parents talked on a hand-held phone, $52.2 \%$ talked on a hands-free phone, $33.7 \%$ read text messages, $26.7 \%$ sent 
text messages, and $13.7 \%$ used social network while driving [91]. This could be a very dangerous and continuously increasing phenomenon involving adolescents and future adults.

\section{Cyberbullying}

The increasing rate of cyberbullying is related to a wide availability of smartphones, internet and mobile devices. It may be defined as a form of bullying performed by a person or by a group through an electronic mean and finalized to inflict discomfort, threat, fear or embarassment to the victim [92]. There are different forms of cyberbullying described by literature: phone calls, text messages, pictures/video clips, emails and messaging apps are among the most used [93]. This is a great public health concern: in Italy, 2015 ISTAT data showed that $19.8 \%$ of $11-17$ years old internet users, report being cyberbullied [94-96].

\section{Hikikomori}

A social phenomenon called Shakaiteki hikikomori (social withdrawal) is becoming increasingly recognized in several Countries [97]. To date, it has been estimated that approximately 1-2\% of adolescents and young adults are hikikomori in Asian countries. Most of them are males and experience a social reclusion ranges from 1 to 4 years [98-104]. They refuse to communicate even with their own family, continuously use Internet and only venture out to deal with their bodily needs.

Many hikikomori spends even more than $12 \mathrm{~h}$ a day in front of a screen and consequently is at high risk of internet addiction [105-107].

\section{Positive aspects}

Smartphone and Internet have also been related to numerous positive aspects concerning with social interactions and communication, developmental and psychology features.

Adolescents may improve self-control, express opinions and reflective decisions [108].

Adolescents who feel isolated and depressed, may establish relationships without concerning about how others evaluate their physical aspect, improve their depressed mood and gain support to increase their self-esteem and peer acceptance and obtain emotional support [109-113].

Results are summarized in Table 1.

\section{Discussion}

\section{Advices}

\section{To parents}

On the base of literature reports, parents should be aware of positive and negative effects of smartphone and media device use in adolescents. Consequently, actionoriented recommendations for families include:
- Improve communication: invite adolescents to critically discuss about the time they spent on media device and about the social app they use. Encourage them sharing problems they may experience offline and online. Aware them on online content and on online privacy.

- Monitor: verify the time spent online and the contents; promote active discussion about media device use; suggest co-view and co-play.

- Define clear policies and regulations: avoid media device use during meals, homeworks and bed-time.

- Give the example: reduce time spent using smartphones during family meeting, when crossing the street and during meals.

- Collaboration: create a network with pediatricians and health care providers in order to aware adolescent internet and smartphones disorders.

\section{To clinicians}

On the base of literature reports, recommendations for clinicians and health care providers include:

- Communication with adolescents and parents: inform adolescents on positive and on negative effects of media device use. Provide information on: addiction risk, distraction, academic outcomes, neuropsychological consequences, comprehension. Discuss with adolescents about their smartphones and social network use, approaching it in a more conscious and informed way. Reflect with teens and parents about how screen-based distractions around are linked with impaired academic performance and how parents are an important model for their children.

- Social networks and positive aspects: discourage adolescents use of social network and smartphones just to avoid solitude and to increase self-esteem; promote a safe use of media to connect with friends and share contents.

- Improve student-student relationship: promote face-to face relationship with adolescents and family.

- Recognize changes in health and social behaviour: in order to promptly copy with smartphone addiction and to minimize negative effects, clinicians should recognize symptoms and signs suggestive for a not correct media device use, such as weight gain/loss, headaches and muscle pain, vision/eye disturbances, etc.

- Educate: introduce screening questions about child's on-line life into the general pediatric visit, including questions about video game use and cyberbullying, in order to identify adolescents that are engaging in health risk behaviours or addiction problems.

Advices are summarized in Table 2. 
Table 1 Main reviewed articles and their principal features

\begin{tabular}{|c|c|c|c|c|c|c|}
\hline DOMAIN & REFERENCE & $\begin{array}{l}\text { TYPE } \\
\text { OF } \\
\text { STUDY } \\
\text { DESIGN }\end{array}$ & METHOD & MAIN INSTRUMENTS USED & $\begin{array}{l}\text { OUTCOMES' ANALISYS } \\
\text { AND/OR } \\
\text { STANDARDIZED } \\
\text { GRADING OF EVIDENCE } \\
\text { LEVEL APPLIED }\end{array}$ & $\begin{array}{l}\text { HIGHLIGHTED } \\
\text { PROS/CONS }\end{array}$ \\
\hline \multirow[t]{5}{*}{ Learning } & $\begin{array}{l}\text { Rogaten J et al., } \\
2013 \text { [15] }\end{array}$ & CS & $\begin{array}{l}\text { Online } \\
\text { survey }\end{array}$ & $\begin{array}{l}\text { Approaches and Study Skills Inventory for } \\
\text { Students, the Positive and Negative Affect } \\
\text { Schedule, the Evaluation Anxiety Scales }\end{array}$ & SA & \multirow{5}{*}{$\begin{array}{l}\text { Low academic } \\
\text { outcomes, } \\
\text { reduction of } \\
\text { concentration, } \\
\text { reduction of } \\
\text { creativity, } \\
\text { reduction of } \\
\text { comprehension, } \\
\text { reduction of } \\
\text { organization }\end{array}$} \\
\hline & $\begin{array}{l}\text { Kirschner PA et al., } \\
2016[16]\end{array}$ & CS & $\begin{array}{l}\text { Customized } \\
\text { survey }\end{array}$ & $\begin{array}{l}\text { Five sections of closed-response (e.g., } \\
\text { Likert-type scaling) and open-response } \\
\text { items. }\end{array}$ & SA & \\
\hline & $\begin{array}{l}\text { Lopez-Fernandez O } \\
\text { et al., } 2017 \text { [18] }\end{array}$ & CS & $\begin{array}{l}\text { Online } \\
\text { survey }\end{array}$ & $\begin{array}{l}\text { The dependence subscale of a short } \\
\text { version of the Problematic Mobile Phone } \\
\text { Use Questionnaire }\end{array}$ & SA & \\
\hline & $\begin{array}{l}\text { Arquero JL, at al., } \\
2015[22]\end{array}$ & CS & $\begin{array}{l}\text { Customized } \\
\text { survey }\end{array}$ & $\begin{array}{l}\text { New Study Process Questionnaire (N-SPQ-3f) and Academic } \\
\text { Motivation Scale }\end{array}$ & $\begin{array}{l}\text { Statistical and } \\
\text { comparative subgroups' } \\
\text { analysis of the observed } \\
\text { data }\end{array}$ & \\
\hline & $\begin{array}{l}\text { Rozgonjuk D et al., } \\
2018 \text { [24] }\end{array}$ & CS & $\begin{array}{l}\text { Online } \\
\text { survey }\end{array}$ & $\begin{array}{l}\text { Estonian Smartphone Addiction Proneness Scale and the } \\
\text { Estonian Revised Study Process Questionnaire }\end{array}$ & SA & \\
\hline \multirow[t]{5}{*}{ Sleep } & $\begin{array}{l}\text { Charter B et al., } \\
2016[25]\end{array}$ & MA & RW & $\begin{array}{l}24 \mathrm{MeSH} \text { terms, titles and abstracts were screened for } \\
\text { relevance }\end{array}$ & $\begin{array}{l}\text { Statistical heterogeneity } \\
\text { was assessed using the } \\
12 \text { statistic }\end{array}$ & \multirow{5}{*}{$\begin{array}{l}\text { Increase of sleep } \\
\text { latency, } \\
\text { increase of arousals, } \\
\text { reduction of sleep } \\
\text { duration, } \\
\text { metabolic issues }\end{array}$} \\
\hline & $\begin{array}{l}\text { Prather AA et al., } \\
2014 \text { [31] }\end{array}$ & CS & $\begin{array}{l}\text { Longitudinal } \\
\text { study }\end{array}$ & NA & SA & \\
\hline & $\begin{array}{l}\text { Caine } N \text { et al., } 2010 \\
\text { [37] }\end{array}$ & DS & RW & Literature Research & SA & \\
\hline & Bixler E, 2009 [41] & DS & RW & Literature Research & SA & \\
\hline & Owens J, 2014 [42] & DS & RW & Literature Research & SA & \\
\hline \multirow[t]{3}{*}{ Sight } & $\begin{array}{l}\text { Fenga C et al., } 2014 \\
{[47]}\end{array}$ & CC & NA & Ocular examination and questionnaire & SA & \multirow{3}{*}{$\begin{array}{l}\text { Dry eye disease, } \\
\text { eye irritation and } \\
\text { burning sensation, } \\
\text { conjunctival } \\
\text { injection, } \\
\text { decrease visual } \\
\text { acuity, } \\
\text { acute acquired } \\
\text { comitant esotropia, } \\
\text { macular } \\
\text { degeneration }\end{array}$} \\
\hline & $\begin{array}{l}\text { Moon JH et al., } \\
2014[48]\end{array}$ & $\mathrm{CC}$ & NA & Ocular examination and questionnaire & SA & \\
\hline & $\begin{array}{l}\text { Moon JH et al., } \\
2016[49]\end{array}$ & CC & NA & Ocular examination and questionnaire & SA & \\
\hline \multirow[t]{6}{*}{ Addiction } & $\begin{array}{l}\text { Chotpitayasunondh } \\
\text { V et al., } 2016 \text { [54] }\end{array}$ & CS & $\begin{array}{l}\text { Online } \\
\text { survey }\end{array}$ & $\begin{array}{l}\text { Phubbing questionnaire, Smartphone Addiction Scale Short } \\
\text { Version (SAS-SV), Internet Addiction Test (IAT), Fear of Missing } \\
\text { Out Scale (FoMOs), and Brief Self-Control Scale (BSCS) }\end{array}$ & $\begin{array}{l}\text { Statistical analysis of the } \\
\text { observed data }\end{array}$ & \multirow{6}{*}{$\begin{array}{l}\text { Fear of missing out, } \\
\text { wish to remain } \\
\text { constantly } \\
\text { connected, } \\
\text { necessity to check } \\
\text { continuously social } \\
\text { app, } \\
\text { boredom, } \\
\text { lack of } \\
\text { psychological } \\
\text { involvement, } \\
\text { lack of interest } \\
\text { dissatisfaction }\end{array}$} \\
\hline & $\begin{array}{l}\text { Wegmann E et al., } \\
2016[55]\end{array}$ & CS & Survey & $\begin{array}{l}\text { Modified Version of the Short Internet Addiction Test, internet- } \\
\text { Use Expectancies Scale, Brief COPE, elf-Efficacy Scale, Brief } \\
\text { Symptom Inventor, }\end{array}$ & $\begin{array}{l}\text { Statistical analysis of the } \\
\text { observed data }\end{array}$ & \\
\hline & $\begin{array}{l}\text { Choi SW et al., } 2015 \\
\text { [60] }\end{array}$ & CS & Survey & $\begin{array}{l}\text { Smartphone Addiction Scale, the Young Internet Addiction } \\
\text { Test, the Alcohol } \\
\text { Use Disorders Identification Test, the Beck Depression Inventory } \\
\text { l, the State-Trait Anxiety Inventory (Trait } \\
\text { Version), the Character Strengths Test, and the Connor- } \\
\text { Davidson Resilience Scale }\end{array}$ & $\begin{array}{l}\text { Multiple linear } \\
\text { regression analyses of } \\
\text { observed data }\end{array}$ & \\
\hline & $\begin{array}{l}\text { Long J et al., } 2016 \\
\text { [62] }\end{array}$ & CS & Survey & $\begin{array}{l}\text { Socio-demographic, smartphone use feature, problematic } \\
\text { Cellular Phone Use Questionnaire (PCPUQ), Chinese Frost } \\
\text { Multidimensional Perfectionism Scale (CFMPS), Zung Self-Rating } \\
\text { Depression Scale (SDS), Zung Self-Rating Anxiety Scale (SAS), } \\
\text { Perceived Stress Scale (PSS) }\end{array}$ & $\begin{array}{l}\text { Statistical analysis of the } \\
\text { observed data }\end{array}$ & \\
\hline & $\begin{array}{l}\text { Jia R et al., } 2016 \\
\text { [65] }\end{array}$ & $\mathrm{CHS}$ & $\begin{array}{l}\text { Anonymous } \\
\text { survey }\end{array}$ & $\begin{array}{l}\text { Measurement scales to assess PIU and parental attachment } \\
\text { (both maternal and paternal) }\end{array}$ & $\begin{array}{l}\text { Ordinary least squares } \\
\text { regression }\end{array}$ & \\
\hline & $\begin{array}{l}\text { Liu M et al. } 2016 \\
\text { [67] }\end{array}$ & MA & $\begin{array}{l}\text { PRISMA } \\
\text { guideline }\end{array}$ & $\begin{array}{l}\text { Electronic databases of PubMed, Web of Science and EBSCO } \\
\text { systematically review }\end{array}$ & $\begin{array}{l}\text { Generalised least } \\
\text { squares trend } \\
\text { estimation }\end{array}$ & \\
\hline \multirow[t]{3}{*}{ Muscle } & $\begin{array}{l}\text { Lee JH et al., } 2014 \\
\text { [81] }\end{array}$ & CC & Survey & Questionnaires & SA & \multirow{3}{*}{$\begin{array}{l}\text { Neck pain, } \\
\text { shoulder pain, } \\
\text { wrist and finger } \\
\text { pain, } \\
\text { vehicle crashes, } \\
\text { traffic accident }\end{array}$} \\
\hline & $\begin{array}{l}\text { Kang JH et al., } 2012 \\
\text { [83] }\end{array}$ & CC & Survey & Computer software & SA & \\
\hline & Collet C et al.,2010 & DS & Survey & Questionnaires & SA & \\
\hline
\end{tabular}


Table 1 Main reviewed articles and their principal features (Continued)

\begin{tabular}{|c|c|c|c|c|c|c|}
\hline DOMAIN & REFERENCE & $\begin{array}{l}\text { TYPE } \\
\text { OF } \\
\text { STUDY } \\
\text { DESIGN }\end{array}$ & METHOD & MAIN INSTRUMENTS USED & $\begin{array}{l}\text { OUTCOMES' ANALISYS } \\
\text { AND/OR } \\
\text { STANDARDIZED } \\
\text { GRADING OF EVIDENCE } \\
\text { LEVEL APPLIED }\end{array}$ & $\begin{array}{l}\text { HIGHLIGHTED } \\
\text { PROS/CONS }\end{array}$ \\
\hline \multirow[t]{4}{*}{ Distraction } & $\begin{array}{l}\text { Collet C et al.,2010 } \\
\text { [87] }\end{array}$ & DS & Survey & Questionnaires & SA & \multirow[t]{4}{*}{$\begin{array}{l}\text { Vehicle crashes, } \\
\text { traffic accidents }\end{array}$} \\
\hline & $\begin{array}{l}\text { Stelling-Konczak A } \\
\text { et al., } 2017 \text { [90] }\end{array}$ & DS & Survey & Questionnaire & SA & \\
\hline & $\begin{array}{l}\text { Byington KW et al., } \\
2013 \text { [91] }\end{array}$ & CS & Survey & Virtual pedestrian street Questionnaire & SA & \\
\hline & $\begin{array}{l}\text { Bingham CR et al., } \\
2015 \text { [93] }\end{array}$ & DS & Survey & $\begin{array}{l}\text { National sample of } 403 \text { parent-teen dyads using random-digit } \\
\text { dialing telephone interviews. }\end{array}$ & $\begin{array}{l}\text { Bingham CR et al., } 2015 \\
\text { [93] }\end{array}$ & \\
\hline \multirow[t]{2}{*}{ Cyberbullying } & $\begin{array}{l}\text { Tokunaga RS, } 2010 \\
\text { [94] }\end{array}$ & RW & Survey & Questionnaires & SA & \multirow{2}{*}{$\begin{array}{l}\text { Social discomfort, } \\
\text { exclusion, } \\
\text { alienation, }\end{array}$} \\
\hline & $\begin{array}{l}\text { Smith PK et al., } \\
2008 \text { [95] }\end{array}$ & DS & Survey & Questionnaires & SA & \\
\hline \multirow[t]{3}{*}{ Hikikomori } & $\begin{array}{l}\text { Stip E et al., } 2016 \\
{[105]}\end{array}$ & DS & RW & $\begin{array}{l}\text { Medline up to 12th May, } 2015 \text { supplemented by a hand search } \\
\text { of the bibliographies of all retrieved articles. }\end{array}$ & SA & \multirow{3}{*}{$\begin{array}{l}\text { Absence of human- } \\
\text { human interaction } \\
\text { and } \\
\text { communication }\end{array}$} \\
\hline & $\begin{array}{l}\text { Lee YS et al., } 2013 \\
{[106]}\end{array}$ & CC & Interview & $\begin{array}{l}\text { Participants' Depression Inventory, Trait Anxiety Inventory, } \\
\text { Social Anxiety Scale, and Internet Addiction Scale scores. }\end{array}$ & SA & \\
\hline & $\begin{array}{l}\text { Li TM et al., } 2015 \\
{[107]}\end{array}$ & DS & RW & $\begin{array}{l}\text { ProQuest, ScienceDirect, Web of Science and PubMed, } \\
\text { quantitative and qualitative studies of socially withdrawn } \\
\text { youths published in English and academic peer-reviewed } \\
\text { journals. }\end{array}$ & NA & \\
\hline \multirow[t]{4}{*}{$\begin{array}{l}\text { Positive } \\
\text { aspects }\end{array}$} & $\begin{array}{l}\text { Ferrara P et al., } 2014 \\
{[109]}\end{array}$ & DS & $\begin{array}{l}\text { Customized } \\
\text { internet- } \\
\text { based }\end{array}$ & $\begin{array}{l}\text { Newspaper indexes, news websites and internet search } \\
\text { engines such as Google were used. }\end{array}$ & DS & \multirow{4}{*}{$\begin{array}{l}\text { Improvement of } \\
\text { self-control, } \\
\text { improvement of } \\
\text { communication } \\
\text { among depressed } \\
\text { children, } \\
\text { improvement of } \\
\text { communication } \\
\text { among insecure } \\
\text { adolescents, } \\
\text { improvement of } \\
\text { capacity to express } \\
\text { opinions }\end{array}$} \\
\hline & $\begin{array}{l}\text { Petry NM et al., } \\
2014[110]\end{array}$ & RW & $\begin{array}{l}\text { Experts' } \\
\text { estimations }\end{array}$ & Cross-cultural experts' collaboration & NA & \\
\hline & $\begin{array}{l}\text { Ferrara P et al., } 2018 \\
\text { [111] }\end{array}$ & DS & RW & NA & NA & \\
\hline & $\begin{array}{l}\text { Baer S et al., } 2011 \\
{[112]}\end{array}$ & CS & Survey & Computer/Gaming-station Addiction Scale & SA & \\
\hline
\end{tabular}

Legend as follow: NA, not available feature; CC, case control; DS, descriptive study; $\mathrm{CHS}$, cohort study; RP, report; RW, review; MA, metanalysis; SA, statistical analysis

Table 2 Advices to parents and clinicians on media use during adolescence

\begin{tabular}{|c|c|c|c|}
\hline \multicolumn{4}{|l|}{ ADVICES } \\
\hline ITEM & TO PARENTS & ITEM & TO CLINICIANS \\
\hline Communication & $\begin{array}{l}\text { - Create open communication sharing } \\
\text { problems and difficulties } \\
\text { - Remind the need to protect online } \\
\text { privacy } \\
\text { - Encourage critical thinking about media }\end{array}$ & Communication & $\begin{array}{l}\text { - Provide to adolescents Information about positive and negative effects of media use } \\
\text { - Reflect with teens about worsening of academic performances }\end{array}$ \\
\hline Monitoring & $\begin{array}{l}\text { - Time spent online } \\
\text { - The appropriate technology for each } \\
\text { stage of development. } \\
\text { - Contents }\end{array}$ & Positive aspects & $\begin{array}{l}\text { - Promote face-to face interaction } \\
\text { - Encourage a safe use of media } \\
\text { - Promote media use to share contents with friends }\end{array}$ \\
\hline Rules & $\begin{array}{l}\text { - No media use during meals } \\
\text { - No media use during home-works } \\
\text { - No media use during bed time }\end{array}$ & $\begin{array}{l}\text { Physical } \\
\text { examination and } \\
\text { education }\end{array}$ & $\begin{array}{l}\text { - Introduce screening questions about media use during general visit } \\
\text { - Recognize symptoms and signs suggestive for a not correct media use: weight loss/gain } \\
\text { headaches, muscle discomfort, eyes disturbances, psychological problems }\end{array}$ \\
\hline $\begin{array}{l}\text { Give the } \\
\text { example }\end{array}$ & $\begin{array}{l}\text { - Restrict time spent using smartphone } \\
\text { during family meetings } \\
\text { - Do not use smartphones when driving } \\
\text { and during meals. } \\
\text { - Choose appropriate contents for online } \\
\text { communication and social network }\end{array}$ & Collaboration & - Create a network with families and health care providers \\
\hline Collaboration & $\begin{array}{l}\text { - Create a network with pediatrician and } \\
\text { health care providers }\end{array}$ & & \\
\hline
\end{tabular}




\section{Conclusion}

Smartphones and social network have become integral part of adolescent's life influencing the person's whole life. Both parents and clinicians/ health care providers should understand both potential benefits and risks in order to prevent negative consequences, such as smartphone addiction. Both clinicians and parents should strive to better understand adolescent online activities, discuss with them about smartphone use and prevent adverse events.

\section{Acknowledgements}

Not applicable.

\section{Consent to publication}

Not applicable.

Availability of material:

The materials analyzed during the current study are available at Bambino Gesù Children Hospital, Rome at the room of Dr. Bozzola.

\section{Authors' contributions}

$E B, M B$ coordinated the study; GC, AV designed the study; GS and MR, DV analyzed the literature on sight, muscle, sleep; CC, AMS analyzed the literature on addiction and distraction; RA and ADV analyzed the literature on learning; GB and $A C$ analyzed the literature on cyberbullying ad Hikikomori; LM and RT analyzed the positive aspects of media device use. All authors read and approved the final version.

\section{Funding}

No funding.

\section{Ethics approval and consent to participate}

Not applicable.

\section{Competing interests}

No competing interests.

\section{Author details}

${ }^{1}$ Italian Pediatric Society, Rome, Italy. ${ }^{2}$ University of Tor Vergata, Rome, Italy.

Received: 21 May 2019 Accepted: 26 September 2019

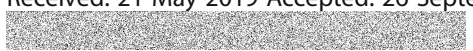

\section{References}

1. Bozzola E, Spina G, Ruggiero M, Memo L, Agostiniani R, Bozzola M, Corsello G, Villani A. Media devices in pre-school children: the recommendations of the Italian pediatric society. Ital J Pediatr. 2018;44:69.

2. The statistics portal. 2018 www.statista.com

3. Oberst U, Renau V, Chamarro A, Carbonell X. Gender stereotypes in Facebook profiles: are women more female online? Comput Hum Behav. 2016;60:559-64.

4. Indagine Conoscitiva su bullismo e cyberbullismo. Commissione parlamentare infanzia e adolescenza. 27 marzo 2019 www.istat.it

5. Bagot KS, Milin R, Kaminer Y. Adolescent initiation of cannabis use and early onset psychosis. Subst Abuse. 2015;36(4):524-33.

6. Teens, social media \& Technology 2018. Pew Reserch Center, May 2018. www.pewinternet.org/2018/05/31/teens-social-media-technology-2018/

7. We are social-Hootsuite. Digital in 2019 www.wearesocial.com

8. Internet use and activities. Eurostat. 2017. www.ec.europa.eu/eurostat

9. Number of smartphone users worldwide from 2014 to 2020 (in billions). Statista 2017. www.statista.com

10. Li Y, Zhang X, Lu F, Zhang Q, Wang Y. Internet addiction among elementary and middle school students in China: a nationally representative sample study. Cyberpsychol Behav Soc Netw. 2014;17:111-6.

11. Mihara S, Osaki Y, Nakayama H, Sakuma H, Ikeda M, Itani O, Kaneita Y, et al. Internet use and problematic internet use among adolescents in Japan: a nationwide representative survey. Addict Behav Rep. 2016;4(Suppl. C):58-64.
12. Sanjeev D, Davey A, Singh J. Emergence of problematic internet use among Indian adolescents: a multi method study. Child Adolesc Ment Health 2016;12:60-78

13. https://www.adolescienza.it/osservatorio/adolescenti-iperconnessi-likeaddiction-vamping-e-challenge-sono-le-nuove-patologie/

14. Rapporto Censis sulla situazione sociale del Paese. 2018: 465-470.

15. Rogaten J, Moneta GB, Spada MM. Academic performance as a function of approaches to studying and affect in studying. J Happiness Stud. 2013;14:1751-63.

16. Kirschner PA, Karpinski AC. Facebook and academic performance. Comput Hum Behav. 2010:26:1237-45.

17. Dewitte S, Schouwenburg HC. Procrastination, temptations, and incentives: the struggle between the present and the future in procrastinators and the punctual. Eur J Personal. 2002;16:469-89.

18. Lopez-Fernandez O, Kuss DJ, Romo L, Morvan Y, Kern L, Graziani P, Rousseau A, Rumpf HJ, Bischof A, Gässler AK, et al. Self-reported dependence on mobile phones in young adults: a European cross-cultural empirical survey. J Behav Addict. 2017;6:168-77.

19. Warburton K. Deep learning and education for sustainability. Int J Sustain High Educ. 2003;4:44-56.

20. Chin C, Brown DE. Learning in science: a comparison of deep and surface approaches. JRes Sci Teach. 2000;37:109-38.

21. Hoeksema LH. Learning strategy as a guide to career success in organizations. Leiden University: The Netherlands. DSWO Press, 1995.

22. Arquero JL, Fernández-Polvillo C, Hassall T, Joyce J. Vocation, motivation and approaches to learning: a comparative study. Educ Train. 2015;57:13-30.

23. Gynnild V, Myrhaug D. Revisiting approaches to learning in science and engineering: a case study. Eur J Eng Educ. 2012;37:458-70.

24. Rozgonjuk D, Saal K, Täht K. Problematic smartphone use, deep and surface approaches to learning, and social media use in lectures. Int J Environ Res Public Health. 2018;15:92

25. Carter B, Rees P, Hale L, Bhattacharjee D, Paradkar MS. Association between portable screen-based media device access or use and sleep outcomes a systematic review and meta-analysis. JAMA Pediatr. 2016;170(12):1202-8.

26. Lanaj K, Johnson RE, Barnes CM. Beginning the workday yet already depleted? Consequences of late-night smartphone use and sleep. Organ Behav Hum Decis Process. 2014;124(1):11-23.

27. Lemola S, Perkinson-Gloor N, Brand S, Dewald-Kaufmann JF, Grob A Adolescents' electronic media use at night, sleep disturbance, and depressive symptoms in the smartphone age. Journal of Youth and Adolescence. 2015:44(2):405-18.

28. Park S, Cho MJ, Chang SM, Bae JN, Jeon HJ, Cho SJ, Kim BS, et al. Relationships of sleep duration with sociodemographic and health-related factors, psychiatric disorders and sleep disturbances in a community sample of Korean adults. J Sleep Res. 2010;19(4):567-77.

29. Bao Z, Chen C, Zhang W, Jiang Y, Zhu J, Lai X. School connectedness and Chinese adolescents' sleep problems: a cross-lagged panel analysis. J Sch Health. 2018;88(4):315-21.

30. Cain N, Gradisar M. Electronic media use and sleep in school-aged children and adolescents: a review. Sleep Med. 2010;11(8):735-42.

31. Prather AA, Puterman E, Epel ES, Dhabhar FS. Poor sleep quality potentiates stress-induced cytokine reactivity in postmenopausal women with high visceral abdominal adiposity. Brain Behav Immun. 2014;35(1):155-62.

32. Nagane M, Suge R, Watanabe SI. Time or retiring and sleep quality may be predictors of academic performance and psychosomatic disorder in university students. Biol Rhythm Res. 2016;47(2):329-37.

33. Waller EA, Bendel RE, Kaplan J. Sleep disorders and the eye. Mayo Clin Proc. 2008:83(11):1251-61.

34. Ivarsson $\mathrm{M}$, Anderson $\mathrm{M}$, Åkerstedt $\mathrm{T}$, Lindblad F. Playing a violent television game affects heart rate variability. Acta Paediatr. 2009;98(1):166-72.

35. Hysing M, Pallesen S, Stormark KM, Lundervold AJ, Sivertsen B. Sleep patterns and insomnia among adolescents: a population-based study. J Sleep Res. 2013:22:549-56.

36. Li S, Jin X, Wu S, Jiang F, Yan C, Shen X. The impact of media use on sleep patterns and sleep disorders among school-aged children in China. Sleep. 2007;30(3):361-7.

37. Cain N, Gradisar M. Electronic media use and sleep in school-aged children and adolescents: a review. Sleep Med. 2010;11:735-42.

38. Weaver E, Gradisar M, Dohnt H, Lovato N, Douglas P. The effect of presleep videogame playing on adolescent sleep. J Clin Sleep Med. 2010;6:184-9. 
39. Thomee S, Dellve L, Harenstam A, Hagberg M. Perceived connections between information and communication technology use and mental symptoms among young adults-a qualitative study. BMC Public Health. 2010;10:66.

40. Altman NG, Izci-Balserak B, Schopfer E, Jackson N, Rattanaumpawan P, Gehrman PR, Patel NP, et al. Sleep duration versus sleep insufficiency as predictors of cardiometabolic health outcomes. Sleep Med. 2012;13(10): 1261-70.

41. Bixler E. Sleep and society: an epidemiological perspective. Sleep Med. 2009;10(1).

42. Owens J. Insufficient sleep in adolescents and young adults: an update on causes and consequences. Pediatrics. 2015;134(3):921-32.

43. Continente X, Pérez A, Espelt A, Lopez MJ. Media devices, family relationships and sleep patterns among adolescents in an urban area. Sleep Med. 2017:32:28-35.

44. Smick K. Guarding your patient's eyes for harmful light: part one: the importance of education. Rev Optom. 2014;151:26-8.

45. Bergqvist UO, Knave BG. Eye discomfort and work with visual display terminals. Scand J Work Environ Health. 1994;20:27-33.

46. Freudenthaler N, Neuf H, Kadner G, Schlote T. Characteristics of spontaneous eyeblink activity during video display terminal use in healthy volunteers. Graefes Arch Clin Exp Ophthalmol. 2003;241:914-20.

47. Fenga C, Aragona P, Di Nola C, Spinella R. Comparison of ocular surface disease index and tear osmolarity as markers of ocular surface dysfunction in video terminal display workers. Am J Ophthalmol. 2014;158:41-8.

48. Moon JH, Lee MY, Moon NJ. Association between video display terminal use and dry eye disease in school children. J Pediatr Ophthalmol Strabismus. 2014;51(2):87-92.

49. Moon $\mathrm{JH}$, Kim KW, Moon NJ. Smartphone use is a risk factor for pediatric dry eye disease according to region and age: a case control study. BMC Ophthalmol. 2016;16:188.

50. Clark AC, Nelson LB, Simon JW, Wagner R, Rubin SE. Acute acquired comitant esotropia. Br J Ophthalmol. 1989;73:636-8.

51. Lee HS, Park SW, Heo H. Acute acquired comitant esotropia related to excessive smartphone use. BMC Ophthalmol. 2016;16:37.

52. Kwon M, Kim DJ, Cho H, Yang S. The Smartphone Addiction Scale: Development and Validation of a Short Version for Adolescents. PLoS ONE. 2013; 8(12).

53. Choi SW, Kim DJ, Choi JS, Ahn H, Choi EJ, Song WY, Kim S, et al. Comparison of risk and protective factors associated with smartphone addiction and internet addiction. J Behav Addict. 2015;4(4):308-14

54. Chotpitayasunondh V, Douglas KM. How "phubbing" becomes the norm: the antecedents and consequences of snubbing via smartphone. Comput Hum Behav. 2016;63:9-18.

55. Wegmann E, Brand M. Internet-communication disorder: It's a matter of social aspects, coping, and internet-use expectancies. Front Psychol. 2016; 7(1747):1-14.

56. Lin $\mathrm{YH}$, Chiang $\mathrm{CL}$, Lin $\mathrm{PH}$, Chang LR, Ko CH, Lee YH, Lin SH. Proposed Diagnostic Criteria for Smartphone Addiction. PLOS ONE. 2016;11.

57. Teen Smartphone Addiction National Survey questionnaire. www. screeneducation.org

58. National Information Society Agency. Internet addiction survey 2011. Seoul: National Information Society Agency. 2012:118-9.

59. Bae SM. Smartphone addiction of adolescents, not a smart choice. J Korean Med Sci. 2017:32:1563-4.

60. Choi SW, Kim DJ, Choi JS, Ahn H, Choi EJ, Song WY, Kim S, et al. Comparison of risk and protective factors associated with smartphone addiction and internet addiction. J Behav Addict. 2015;4(4):308-14.

61. Weiser EB. Gender differences in internet use patterns and internet application preferences: a two-sample comparison. CyberPsychol Behav. 2004;3:167-78.

62. Long J, Liu TQ, Liao YH, Qi C, He HY, Chen SB, Billieux J. Prevalence and correlates of problematic smartphone use in a large random sample of Chinese undergraduates. BMC Psychiatry. 2016;16:408.

63. Lee H, Kim JW, Choi TY. Risk factors for smartphone addiction in Korean adolescents: smartphone use patterns. J Korean Med Sci. 2017;32:1674-9.

64. Lam LT, Peng ZW, Mai JC, Jing J. Factors associated with internet addiction among adolescents. Cyberpsychol Behav. 2009;12(5):551-5.

65. Jia R, Jia HH. Maybe you should blame your parents: parental attachment, gender, and problematic internet use. J Behav Addict. 2016;5(3):524-8.
66. Bhagat S. Is Facebook a planet of lonely individuals? A review of literature The Interrnational Journal of Indian Psychology. 2015;3(1):5-9.

67. Liu M, Wu L, Yao S. Dose-response association of screen time-based sedentary behavior in children and adolescents and depression: a meta-analysis of observational studies. Br J Sports Med. 2016;50(20):1252-8.

68. $\mathrm{Ihm} \mathrm{J}$. Social implications of children's smartphone addiction: the role of support networks and social engagement. J Behav Addict. 2018;7(2):473-81.

69. Wegmann E, Stodt B, Brand M. Addictive use of social networking sites can be explained by the interaction of internet use expectancies, internet literacy, and psychopathological symptoms. J Behav Addict. 2015;4(3):155-62.

70. Lin LY, Sidani JE, Shensa A, Radovic A, Miller E, Colditz JB, Primack BA. Association between social media use and depression among U.S. young adults. Depress Anxiety. 2016;33(4):323-31.

71. Ko CH, Yen JY, Chen CS, Yeh YC, Yen CF. Predictive values of psychiatric symptoms for internet addiction in adolescents: a 2-year prospective study. Arch Pediatr Adolesc Med. 2009;163(10):937-43.

72. Przybylski AK, Murayama K, DeHaan CR, Gladwell V. Motivational, emotional, and behavioral correlates of fear of missing out. Comput Hum Behav. 2013; 29:1841-8.

73. Biolcati R, Mancini G, Trombini E. Proneness to boredom and risk behaviors during adolescents' free time. Psychol Rep. 2017:1-21.

74. Brissett D, Snow RP. Boredom: where the future isn't. Symb Interact. 1993; 16(3):237-56.

75. Harris MB. Correlates and characteristics of boredom proneness and boredom. J Appl Soc Psychol. 2000;30(3):576-98.

76. Wegmann E, Ostendorf S, Brand M. Is it beneficial to use Internetcommunication for escaping from boredom? Boredom proneness interacts with cue-induced craving and avoidance expectancies in explaining symptoms of Internet-communication disorder. PLOS ONE. 2017;13(4).

77. Wang $P$, Zhao $M$, Wang $X$, Xie $X$, Wang $Y$, Lei L. Peer relationship and adolescent smartphone addiction: the mediating role of self-esteem and the moderating role of the need to belong. J Behav Addict. 2017;6(4):708-17.

78. Ko K, Kim HS, Woo JH. The study of muscle fatique and risks of musculoskeletal system disorders from text inputting on a smartphone. Journal of the Ergonomics Society of Korea. 2013;32(3):273-8.

79. Cao H, Sun Y, Wan Y, Hao J, Tao F. Problematic internet use in Chinese adolescents and its relation to psychosomatic symptoms and life satisfaction. BMC Public Health. 2011;11(1):802

80. Kim HJ, Kim JS. The relationship between smartphone use and subjective musculoskeletal symptoms and university students. J Phys Ther Sci. 2015:27:575-9.

81. Lee $\mathrm{JH}$, Seo KC. The comparison of cervical repositioning errors according to smartphone addiction grades. J Phys Ther Sci. 2014;26(4):595-8.

82. Lee $\mathrm{SJ}$, Kang $\mathrm{H}$, Shin $\mathrm{G}$. Head flexion angle while using a smartphone. Ergonomics. 2015;58(2):220-6.

83. Kang JH, Park RY, Lee SJ, Kim JY, Yoon SR, Jung KI. The effect of the forward head posture on postural balance in long time computer based worker. Ann Rehabil Med. 2012;36(1):98-104.

84. Park JH, Kim JH, Kim JG, Kim KH, Kim NK, Choil W, Lee S, et al. The effects of heavy smartphone use on the cervical angle, pain threshold of neck muscles and depression. Advanced Science and Technology Letters. 2015:91:12-7.

85. Ning XP, Huang YP, Hu BY, Nimbarte AD. Neck kinematics and muscle activity during mobile device operations. Int J Ind Ergon. 2015:48:10-5.

86. Hong JH, Lee DY, Yu JH, Kim YY, Jo YJ, Park MH, Seo D. Effect of the keyboard and smartphone usage on the wrist muscle activities. J Convergence Info Technol. 2013;8(14):472-5

87. Collet C, Guillot A, Petit C. Phoning while driving I: a review of epidemiological, psychological, behavioral and physiological studies. Ergonomics. 2010;53(5):589-601.

88. Chen PL, Pai CW. Pedestrian smartphone overuse and inattentional blindness: an observational study in Taipei. Taiwan BMC Public Health. 2018;18:1342.

89. Centers for Disease Control and Prevention. Ten leading causes of death and injury. 2018. www.cdc.gov

90. Stelling-Konczak A, van Wee GP, Commandeur JJF, Hagenzieker M. Mobile phone conversations, listening to music and quiet (electric) cars: are traffic sounds important for safe cycling? Accid Anal Prev. 2017;106:10-22.

91. Byington KW, Schwebel DC. Effects of mobile internet use on college student pedestrian injury risk. Accid Anal Prev. 2013;51:78-83. 
92. Schwebel DC, Stavrinos D, Byington KW, Davis T, O'Neal EE, De Jong D. Distraction and pedestrian safety: how talking on the phone, texting, and listening to music impact crossing the street. Accid Anal Prev. 2012:445:266-71.

93. Bingham CR, Zakrajsek JS, Almani F, Shope JT, Sayer TB. Do as I say, not as I do: distracted driving behavior of teens and their parents. J Saf Res. 2015;55:21-9.

94. Tokunaga RS. Following you home from school: a critical review and synthesis of research on cyberbullying victimization. Comput Hum Behav. 2010;26:277-87.

95. Smith PK, Mahdavi J, Carvalho M, Fisher S, Russell S, Tippett N. Cyberbullying: its nature and impact in secondary school pupils. J Child Psychol Psychiatry. 2008 Apr;49(4):376-85.

96. II bullismo in Italia: comportamenti offensivi e violenti tra i giovanissimi. http://www.istat.it

97. Kato TA, Kanba S, Teo AR. Hikikomori: experience in Japan and international relevance. World Psychiatry. 2018;17(1):105.

98. Maïa F, Figueiredo C, Pionnié-Dax N, Vellut N. Hikikomori, ces adolescents en retrait. Paris: Armand Colin; 2014.

99. Koyama A, Miyake Y, Kawakami N, Tsuchiya M, Tachimori H, Takeshima T. Lifetime prevalence, psychiatric comorbidity and demographic correlates of "hikikomori" in a community population in Japan. Psychiatry Res. 2010;176(1):69-74.

100. Teo AR. A new form of social withdrawal in Japan: a review of hikikomori. Int J Soc Psychiatry. 2010;56(2):178-85.

101. Wong PW, Li TM, Chan M, Law YW, Chau M, Cheng C, et al. The prevalence and correlates of severe social withdrawal (hikikomori) in Hong Kong: a cross-sectional telephone-based survey study. Int I Soc Psychiatry. 2015;61(4):330-42.

102. Kondo N, Sakai M, Kuroda Y, Kiyota Y, Kitabata Y, Kurosawa M. General condition of hikikomori (prolonged social withdrawal) in Japan: psychiatric diagnosis and outcome in mental health welfare centres. Int I Soc Psychiatry. 2013;59(1):79-86.

103. Malagon-Amor A, Corcoles-Martinez D, Martin-Lopez LM, Perez-Sola V. Hikikomori in Spain: a descriptive study. Int J Soc Psychiatry. 2014;61(5):475-83. https://doi.org/10.1177/0020764014553003.

104. Teo AR, Kato TA. The prevalence and correlates of severe social withdrawal in Hong Kong. Int J Soc Psychiatry. 2015;61(1):102.

105. Stip, Emmanuel, et al. "Internet addiction, hikikomori syndrome, and the prodromal phase of psychosis." Frontiers Psych 7 (2016): 6.

106. Lee YS, Lee JY, Choi TY, Choi JT. Home visitation program for detecting, evaluating and treating socially withdrawn youth in Korea. Psychiatry Clin Neurosci. 2013;67(4):193-202.

107. Li TM, Wong PW. Youth social withdrawal behavior (hikikomori): a systematic review of qualitative and quantitative studies. Aust N Z J Psychiatry. 2015:49(7):595-609.

108. Commissariato di PS, Una vita da social. https://www.commissariatodips.it/ uploads/media/Comunicato_stampa_Una_vita_da_social_4_edizione_2017.pdf.

109. Ferrara P, lanniello F, Cutrona C, Quintarelli F, Vena F, Del Volgo V, Caporale $\mathrm{O}$, et al. A focus on recent cases of suicides among Italian children and adolescents and a review of literature. Ital J Pediatr. 2014 Jul 15;40:69.

110. Petry NM, Rehbein F, Gentile DA, et al. An international consensus for assessing internet gaming disorder using the new DSM-5 approach. Addiction. 2014;109(9):1399-406.

111. Ferrara P, Franceschini G, Corsello G. Gambling disorder in adolescents: what do we know about this social problem and its consequences? Ital J Pediatr. 2018:44:146.

112. Baer S, Bogusz E. Green, DA stuck on screens: patterns of computer and gaming station use in youth seen in a psychiatric clinic. J Can Acad Child Adolesc Psychiatry. 2011;20:86-94.

113. Griffiths, M. D. (2009). "The psychology of addictive behaviour," in Psychology for A2 Level, eds M. Cardwell, L. Clark, C. Meldrum, and A. Waddely (London: Harper Collins), 436-471.

\section{Publisher's Note}

Springer Nature remains neutral with regard to jurisdictional claims in published maps and institutional affiliations.

Ready to submit your research? Choose BMC and benefit from:

- fast, convenient online submission

- thorough peer review by experienced researchers in your field

- rapid publication on acceptance

- support for research data, including large and complex data types

- gold Open Access which fosters wider collaboration and increased citations

- maximum visibility for your research: over $100 \mathrm{M}$ website views per year

At BMC, research is always in progress.

Learn more biomedcentral.com/submissions 